\title{
ANALISIS PERILAKU KONSUMEN TERHADAP BELANJA ONLINE \\ DI PASAR TRADISIONAL KOTA SEMARANG \\ (Studi Kasus Pada Konsumen Situs Tumbasin.id)
}

\section{ANALYSIS OF CONSUMER BEHAVIOR TOWARDS ONLINE SHOPPING \\ IN THE SEMARANG TRADITIONAL MARKET \\ (Case Study on Consumer Tumbasin.id Site)}

\author{
Natanael Arya Nanda Mendrofa ${ }^{1)}$ dan Lasmono Tri Sunaryanto ${ }^{1)}$ \\ ${ }^{1)}$ Fakultas Pertanian dan Bisnis Universitas Kristen Satya Wacana \\ e-mail: natanaelarya46@gmail.com
}

\begin{abstract}
ABSTRAK
Situs Tumbasin.id adalah salah satu situs berbasis online yang bergerak dibidang penjualan kebutuhan pasar yang berada di Kota Semarang. Penelitian ini dilakukan pada bulan Maret-April 2019 dan merupakan penelitian deskriptif kuantitatif. Penelitian ini menganalisis pengaruh harga, promosi, kepercayaan, dan kemudahan penggunaan terhadap minat beli ulang konsumen di situs Tumbasin.id. Metode pengambilan sampel yang digunakan adalah nonprobability sampling. Sampel yang dikumpulkan sebanyak 60 responden yang pernah berbelanja kebutuhan pasar secara online di situs Tumbasin.id, setidaknya pernah berbelanja minimal satu kali. Metode analisis yang digunakan adalah teknik analisis regresi berganda yang meliputi uji validitas, uji realibilitas, uji normalitas, uji t, uji $\mathrm{F}$ dan uji determinasi. Hasil penelitian menunjukan bahwa promosi dan kepercayaan berpengaruh signifikan terhadap minat beli ulang konsumen.
\end{abstract}

Kata Kunci: harga; promosi; kepercayaan; minat beli ulang; Tumbasin.id

\section{ABSTRACT}

Tumbasin.id site is one of the sites online based engaged in the sale of market needs in the city of Semarang. This research was conducted in MarchApril 2019. This type of research is quantitative descriptive. This study analyzes the effect of price, promotion, trust and ease of use on consumer repurchase interests in Tumbasin.id site The sampling method used in this study is nonprobability sampling. Samples collected as many as 60 respondents who have shopped online market needs on the Tumbasin.id site have shopped at least once. The analytical method used is multiple regression analysis techniques which include validity, reliability, normality, t-test, F-test and determination test. The results showed that promotion and trust significantly influence consumer repurchase interests.

Keywords: price; promotion; trust; interest in repurchasing;Tumbasin.id

\section{PENDAHULUAN}

Internet tidak dapat dipisahkan dari kehidupan manusia di masa kini.
Dengan semakin berkembangnya teknologi, pertumbuhan pengguna 
internet juga semakin pesat. Internet dapat diakses di mana saja dan kapan saja pada masa sekarang ini. Hal ini disebabkan akses untuk menggunakan internet semakin berkembang dan menjanjikan untuk menjadi sebuah potensi bisnis. Internet tidak hanya menjadi sebuah media informasi dan komunikasi modern saja, melainkan menjadi kebutuhan yang dimanfaatkan untuk berbagai aktivitas, baik aktivitas bisnis maupun aktivitas perdagangan. Keberadaan media internet saat ini membantu kehidupan umat manusia dalam hal proses komunikasi maupun mendapatkan informasi secara cepat tanpa mengenal batasan. Meningkatnya aktivitas masyarakat ini dapat tercermin dari pemenuhan kebutuhan dengan cara jual beli berbasis internet (online). Manfaat yang didapatkan konsumen dari berbelanja online yaitu kemudahan melakukan transaksi, kepercayaan yang tinggi, harga terjangkau, kemudahan berkomunikasi, dan faktor lainnya.

Aktivitas perdagangan barang dan jasa yang dilakukan melalui media internet salah satunya ialah Electronic Commerce (ECommerce). E-commerce adalah teknik pelaksanaan aktivitas komersial dengan menggunakan berbagai alat elektronik.

Belanja online tidak hanya memberikan manfaat baik akan tetapi juga memberikan risiko, seperti adanya penipuan kartu kredit, pesanan yang tidak terkirim, kurang adanya privasi, dan kurangnya jaminan kualitas. Faktor yang berpengaruh terhadap keputusan pembelian pada toko online menurut Benson, et al. (2007) ialah $e$ commerce, terutama, pemesanan dan pembelian e-commerce, seiring dengan kemampuannya untuk menjelaskan dengan baik hal-hal sebagai berikut: 1) harga, pembelian secara online yang lebih murah daripada metode tradisional; 2) promosi, sarana memasarkan suatu produk atau jasa dengan tujuan membujuk atau menarik calon konsumen; 3) kepercayaan, percaya terhadap orang lain dalam suatu situasi; dan 4) kemudahan penggunaan, tidak menyulitkan pengguna teknologi.

Pada penelitian ini, peneliti mencoba menganalisis perilaku konsumen terhadap keputusan belanja di pasar tradisional melalui situs online Tumbasin.id. 
Tumbasin.id merupakan salah satu layanan e-commerce yang membantu konsumen khususnya di Kota Semarang dalam berbelanja kebutuhan sehari-hari di pasar tradisional.

Tujuan penelitian ini adalah untuk mengetahui pengaruh harga, promosi, kepercayaan dan kemudahan penggunaan terhadap minat beli ulang pada situs Tumbasin.id.

\section{Perilaku Konsumen}

Perilaku konsumen adalah tindakan yang dilakukan konsumen dalam mendapatkan produk atau jasa, yang mana terdapat proses pengambilan keputusan sebelumnya. Perilaku konsumen ditinjau dari tingkat keterlibatan seseorang dalam situasi pembelian. Pada keterlibatan yang berbeda akan menimbulkan perlakuan yang berbeda pula (Tjiptono, 2005).

\section{Faktor yang Mempengaruhi Perilaku Konsumen}

Keadaan dan situasi lapisan masyarakat di mana dilahirkan dan berkembang mempengaruhi perilaku konsumen. Konsumen yang berasal dari lapisan masyarakat atau lingkungan yang berbeda akan mempunyai pendapat, penilaian, sikap, kebutuhan dan selera yang berbeda, sehingga dalam pengambilan keputusan pembelian akan dipengaruhi beberapa faktor (Kotler, 2008).

Harga

Harga adalah ukuran terhadap besar kecilnya nilai kepuasan seseorang terhadap produk yang dibelinya. Seseorang akan berani membayar suatu produk dengan harga yang mahal apabila dia mendapatkan kepuasan yang diharapkannya terhadap produk yang akan dibelinya. Secara historis harga itu ditentukan oleh pembeli dan penjual melalui proses tawar menawar, sehingga terjadilah kesepakatan dengan harga tertentu (Gitosudarmo, 2000).

\section{Promosi}

Promosi adalah suatu bentuk komunikasi pemasaran. Komunikasi pemasaran adalah aktivitas pemasaran yang berusaha menyebarkan informasi, membujuk, dan mengingatkan pasar sasaran atas produknya agar bersedia menerima, 
membeli, dan loyal pada produk yang ditawarkan (Tjiptono, 2001).

\section{Kepercayaan}

Kepercayaan ialah kemauan seseorang untuk bertumpu pada orang lain, di mana kita memiliki keyakinan padanya (Moorman, et al. 1993). Kepercayaan merupakan pondasi dari suatu hubungan antara dua pihak atau lebih yang akan terjadi apabila masing-masing saling mempercayai (Yousafzai, et al., 2003).

\section{Kemudahan Penggunaan}

Kemudahan penggunaan diartikan sebagai persepsi individu yang berbelanja menggunakan teknologi baru akan bebas dari kesulitan dalam berbelanja. Dengan menerapkannya ke dalam konteks penelitian "kemudahan penggunaan" adalah persepsi konsumen bahwa belanja melalui internet akan melibatkan sedikit usaha, sedangkan yang dimaksud dengan "kegunaan" adalah sebagai persepsi konsumen tentang hasil pengalaman berbelanja online.

\section{Keputusan Pembelian}

Keputusan yang diambil oleh pembeli untuk membeli sebenarnya merupakan kumpulan dari sejumlah keputusan. Setiap keputusan untuk membeli tersebut terdapat suatu struktur sebanyak enam komponen yaitu: keputusan tentang jenis produk, bentuk produk, merek, jumlah produk, waktu pembelian, dan cara pembayaran (Kotler, 1996).

\section{Minat Beli Ulang}

Minat beli ulang merupakan tahap kecenderungan yang dimiliki seorang konsumen dalam bertindak sebelum keputusan pembelian dilakukan. Ada beberapa faktor yang mempengaruhi seseorang dalam minat untuk membeli yang berkaitan erat dengan perasaan dan emosi. Minat beli ulang dapat diperkuat dengan perasaan seseorang yang merasa puas dan senang atas produk atau jasa yang dibeli, rasa ketidakpuasan yang dirasakan seseorang akan menurunkan bahkan menghilangkan minat beli ulang (Swastha dan Irawan, 2001).

\section{Konsep E-commerce}

Pengertian e-commerce adalah penggunaan internet dan komputer 
dengan browser untuk mengenalkan, menawarkan, membeli serta menjual produk secara online. Manfaat yang didapat dengan penerapan $e$ commerce di sebuah perusahaan ialah perusahaan dapat memiliki pasar internasional. Bisnis dengan $e$ commerce dapat dijalankan tanpa harus terbentur pada batas negara. Biaya operasional dapat ditekan sekecil mungkin, mempercepat waktu, mengurangi resiko, serta mengurangi penggunaan kertas dalam berbagai aktifitas pengerjaan mulai dari mendesain, memproduksi, pengiriman, pendistribusian hingga proses marketing (McLeod dan Schell, 2008).

\section{Tumbasin.id}

Tumbasin.id adalah sebuah platform situs yang mempermudah pengguna untuk memesan kebutuhan bahan pokok langsung dari pasar tradisional guna memfasilitasi para pembeli yang tidak sempat berbelanja di pasar tradisional. Tumbasin.id memastikan barang yang hendak dibeli oleh pelanggan berkualitas dan disortir terlebih dahulu. Jika ingin berbelanja, pembeli dapat memesan menggunakan situs website mobile Tumbasin.id.

\section{METODE PENELITIAN}

Kegiatan pengumpulan data berlokasi di rumah konsumen situs Tumbasin.id dan di kantor Tumbasin.id di kota Semarang. Penelitian dilakukan pada pengguna situs Tumbasin.id yang telah berbelanja setidaknya satu kali. Pemilihan lokasi penelitian dipilih dengan maksud untuk mengetahui bagaimana perilaku konsumen yang diberikan pada situs Tumbasin.id sehingga mampu mengetahui seberapa puas konsumen terhadap pelayanan situs Tumbasin.id.

Waktu pengumpulan data dilakukan pada bulan Maret-April 2019. Sumber data yang digunakan dalam penelitian ini adalah data primer dan sekunder. Data primer bersumber dari penyebaran kuesioner kepada responden. Data sekunder berasal dari jurnal, artikel, buku yang relevan dan sumber lainnya yang berkaitan dengan variabel yang diteliti.

Teknik pengumpulan sampel dalam penelitian ini menggunakan metode purposive sampling dengan kriteria: konsumen yang pernah 
berbelanja pada situs Tumbasin.id setidaknya satu kali dan cenderung melakukan pembelian ulang.

Jenis data diperoleh menggunakan metode wawancara dan kuesioner. Dalam kuesioner, responden diharuskan untuk menjawab berdasarkan skala penelitian. Skala yang digunakan adalah skala Likert yang memiliki skor 1 sampai 5.

Variabel-variabel

dari

penelitian ini terdiri dari variabel $\mathrm{X}$ (variabel independen) dan $\mathrm{Y}$ (variabel dependen). Variabel independen dalam penelitian ini adalah harga $\left(\mathrm{X}_{1}\right)$, promosi $\left(\mathrm{X}_{2}\right)$, kepercayaan $\left(\mathrm{X}_{3}\right)$, dan kemudahan penggunaan $\left(\mathrm{X}_{4}\right)$ dan variabel dependen dalam penelitian ini adalah minat beli ulang $(\mathrm{Y})$.

\section{Metode Analisis Data}

Analisis data yang digunakan dalam penelitian ini meliputi uji validitas, uji reliabilitas, uji normalitas, uji multikolinearitas, uji heteroskedastisitas, analisis regresi berganda, koefisien determinasi, uji $\mathrm{F}$ dan uji t.

\section{HASIL DAN PEMBAHASAN}

Hasil Uji Validitas dan Reliabilitas

Hasil uji validitas menunjukan keseluruhan item pertanyaan untuk variabel adalah valid, sehingga setiap butir pertanyaan dapat digunakan untuk mengukur variabel penelitian selanjutnya. Indikator dari suatu variabel dikatakan valid apabila $r_{\text {hitung }}$ $>$ dari $\mathrm{r}_{\text {tabel. }}$ Berdasarkan uji reliabilitas, seluruh variabel dalam instrumen penelitian ini dinyatakan reliabel. Hal ini sesuai dengan kriteria yang telah ditentukan dimana nilai Alpha Cronbach's yang dihasilkan masing-masing variabel diatas nilai $>0,7$.

\section{Analisis Regresi Linier Berganda}

Hasil analisis regresi linier berganda, koefisien determinasi, uji hipotesis secara simultan dengan menggunakan bantuan program SPSS 25 sebagai berikut. 
Tabel 1. Hasil Uji Analisis Linier

\begin{tabular}{|c|c|c|c|c|}
\hline \multicolumn{4}{|c|}{ Berganda } & \multirow[b]{2}{*}{ Ket } \\
\hline Var & $\begin{array}{c}\text { Koefisien } \\
\text { Regresi }\end{array}$ & $\begin{array}{c}\mathbf{t} \\
\text { hitung }\end{array}$ & Probabilitas & \\
\hline $\mathbf{X}_{1}$ & 0,077 & 0,732 & 0,467 & $\begin{array}{c}\text { Tidak } \\
\text { Sig. }\end{array}$ \\
\hline $\mathbf{X}_{2}$ & 0,314 & 2,624 & 0,011 & Sig. \\
\hline $\mathbf{X}_{3}$ & 0,430 & 4,062 & 0,000 & Sig. \\
\hline$X_{4}$ & 0,092 & 0,817 & 0,418 & $\begin{array}{l}\text { Tidak } \\
\text { Sig. }\end{array}$ \\
\hline $\mathbf{R}^{2}$ & 0,450 & $F_{\text {tabel }}$ & 2,54 & \\
\hline$\underset{\text { hitumg }}{\mathbf{F}}$ & 11,234 & $\mathrm{t}_{\text {tabel }}$ & 2,004 & \\
\hline $\begin{array}{c}\text { Sig } \\
\text { F }\end{array}$ & 0,000 & & & \\
\hline
\end{tabular}

Minat Beli Ulang $=-1,2480,077 X_{1}+$ $0,314 X_{2}+0,430 X_{3}+0,092 X_{4}$

Sumber: Data Primer yang diolah, 2019

\section{Koefisien Determinasi $\left(\mathbf{R}^{2}\right)$}

Nilai $\mathrm{R}$ Square dalam penelitian ini sebesar 0,450, maka disimpulkan bahwa kemampuan variabel harga, promosi, kepercayaan dan kemudahan penggunaan dalam menjelaskan variasi pada variabel dependen minat beli ulang yaitu sebesar $45 \%$ dan sisanya sebesar 55 $\%$ dipengaruhi variabel lain.

\section{Uji F}

Hasil F-statistik sebesar 11,234 dan tingkat signifikansi $0,000 . \mathrm{F}_{\text {hitung }}$ $(11,234)>F_{\text {tabel }}(2,54)$ dan taraf keyakinan kurang dari 0,05 $(0,000<0,05)$ maka dapat dikatakan variabel independen (harga, promosi, kepercayaan, dan kemudahan penggunaan) berpengaruh terhadap variabel dependen (minat beli ulang).

\section{Uji Hipotesis Secara Parsial (Uji t)}

Dari perhitungan statistik, diperoleh:

Harga $\left(\mathrm{X}_{1}\right)$ diperoleh $\mathrm{t}_{\text {hitung }}$ sebesar $0,732<\mathrm{t}_{\text {tabel }}$ yaitu sebesar 2,004 dan tingkat signifikansi 0,467. Nilai signifikansi tersebut $>0,05$ maka dapat disimpulkan harga tidak berpengaruh signifikan terhadap minat beli ulang.

Promosi $\left(\mathrm{X}_{2}\right)$ diperoleh $\mathrm{t}_{\text {hitung }}$ sebesar 2,624> $t_{\text {tabel }} 2,004$ dan tingkat signifikansi untuk variabel promosi $\left(\mathrm{X}_{2}\right)$ sebesar 0,011. Nilai signifikansi tersebut $<0,05$ maka dapat disimpulkan promosi terbukti berpengaruh positif signifikan terhadap minat beli ulang.

Variabel kepercayaan $\left(\mathrm{X}_{3}\right)$ diperoleh $t_{\text {hitung }}$ sebesar 4,062 $>t_{\text {tabel }}$ 2,004 dan tingkat signifikansi untuk variabel kepercayaan $\left(\mathrm{X}_{3}\right)$ sebesar 0,000 . Nilai signifikansi $0,000<0,05$ maka dapat disimpulkan kepercayaan terbukti berpengaruh positif signifikan terhadap minat beli ulang.

$$
\text { Variabel kemudahan }
$$
penggunaan $\left(\mathrm{X}_{4}\right)$ diperoleh $\mathrm{t}_{\text {hitung }}$ sebesar 0,817 lebih kecil dari $t_{\text {tabel }}$ 2,004 dan tingkat signifikansi untuk variabel kemudahan penggunaan $\left(\mathrm{X}_{4}\right)$ sebesar 0,418 . Oleh karena nilai $\mathrm{t}_{\text {hitung }} 0,817<\mathrm{t}_{\text {tabel }} 2,004$ dan nilai 
signifikansi 0,418>0,05 maka dapat disimpulkan kemudahan penggunaan tidak berpengaruh signifikan terhadap minat beli ulang.

\section{PEMBAHASAN}

\section{Pengaruh Harga $\left(\mathbf{X}_{1}\right)$ terhadap Minat Beli Ulang (Y)}

Hasil dari perhitungan regresi menunjukkan bahwa harga memiliki nilai koefisien sebesar 0,077. Hasil uji $\mathrm{t}$ yang didapatkan yaitu bahwa $t_{\text {hitung }}(0,732)<t_{\text {tabel }}(2,004)$ dan nilai siginifikansi yang didapat sebesar 0,467 atau lebih besar dari 0,05 yang menunjukkan bahwa perubahan harga tidak berpengaruh terhadap minat beli ulang.

Tidak berpengaruhnya harga terhadap minat beli ulang disebabkan karena konsumen merasa harga masih sesuai dengan kualitas produk yang dijual, harga produk masih terjangkau dan harga pada situs Tumbasin.id masih mampu bersaing dengan situs online lainnya serta harga masih sesuai dengan manfaat yang didapat oleh konsumen dari produk tersebut. Sehingga perubahan harga tidak mengurangi minat beli ulang konsumen.

$$
\text { Penelitian Mandey }
$$
menunjukan bahwa harga memiliki pengaruh positif tapi tidak signifikan. Hal ini berarti bahwa konsumen akan memilih produk tanpa memperhatikan harganya. Hasil penelitian ini juga mendukung penelitian yang dilakukan oleh Aptaguna dan Pitaloka (2016), serta Fandiyanto, et al. (2017) yang menyatakan bahwa harga tidak berpengaruh secara signifikan terhadap minat pembelian ulang.

\section{Pengaruh Promosi $\left(\mathrm{X}_{2}\right)$ terhadap Minat Beli Ulang (Y)}

Hasil dari perhitungan regresi menunjukkan bahwa promosi memiliki nilai koefisien sebesar 0,314 . Hasil uji t yang didapatkan yaitu bahwa $t_{\text {hitung }}(2,624)>t_{\text {tabel }}$ $(2,004)$ dan nilai siginifikansi yang didapat sebesar 0,011 atau lebih kecil dari 0,05 yang menunjukkan bahwa promosi berpengaruh terhadap minat beli ulang konsumen.

Ketika konsumen melakukan pembelian produk secara online maka akan dipengaruhi oleh kegiatan promosi baik secara langsung maupun tidak langsung. Kegiatan promosi secara langsung maupun tidak langsung ini dapat dilakukan melalui media cetak, internet dan televisi yang berupa gambar produk 
dengan deskripsi mengenai manfaat produk serta keterangan lainnya yang menguatkan dan meyakinkan konsumen akan produk tersebut sehingga dengan adanya kegiatan promosi dapat mendorong keputusan konsumen untuk melakukan pembelian terhadap produk tersebut.

Hasil penelitian ini didukung oleh penelitian yang dilakukan Jackson (2013) yang menunjukan bahwa promosi memiliki pengaruh signifikan terhadap variabel minat beli ulang. Penelitian menurut Setyarko (2016) juga menyatakan bahwa promosi berpengaruh signifikan terhadap keputusan pembelian produk online.

\section{Pengaruh Kepercayaan $\left(\mathbf{X}_{\mathbf{3}}\right)$ terhadap Minat Beli Ulang (Y)}

Hasil perhitungan regresi menunjukkan bahwa kepercayaan memiliki nilai koefisien sebesar 0,430. Hasil uji t yang didapatkan yaitu bahwa $t_{\text {hitung }}(4,062)>t_{\text {tabel }}$ $(2,004)$ dan nilai siginifikansi yang didapat sebesar 0,000 atau lebih kecil dari 0,05 yang menunjukkan bahwa kepercayaan berpengaruh terhadap minat beli ulang konsumen.

Minat beli ulang konsumen dipengaruhi oleh aspek kepercayaan yang dirasakan konsumen ketika berbelanja secara online di situs Tumbasin.id. Aspek kepercayaan ini dapat berupa pemberian pelayanan yang baik, berkualitas dan berintegritas tinggi yang diberikan oleh situs Tumbasin.id. Kepercayaan terhadap situs Tumbasin.id muncul ketika konsumen merasa aman dengan adanya bukti transaksi dan testimoni dari pembeli lain, kerahasiaan dan jaminan terkait keamanan data diri konsumen terlindungi dan konsumen akan mendapatkan penggantian produk apabila produk yang didapatkan tidak sesuai harapan.

Hasil penelitian ini didukung oleh penelitian yang dilakukan Murwatiningsih dan Apriliani (2013) yang menunjukkan bahwa kepercayaan memiliki pengaruh positif signifikan terhadap variabel minat beli ulang. Penelitian Fandiyanto, et al. (2017) juga menyatakan bahwa kepercayaan berpengaruh signifikan terhadap keputusan pembelian produk kerajinan danbo secara online. 
PengaruhKemudahan Penggunaan $\left(\mathrm{X}_{4}\right)$ terhadap Minat Beli Ulang (Y)

Hasil perhitungan regresi menunjukkan bahwa kemudahan penggunaan memiliki nilai koefisien sebesar 0,092. Hasil uji $\mathrm{t}$ yang didapatkan yaitu bahwa $t_{\text {hitung }}(0,817)$ $<\mathrm{t}_{\text {tabel }}(2,004)$ dan nilai siginifikansi yang didapat sebesar 0,418 atau lebih besar dari 0,05 yang menunjukkan bahwa kemudahan penggunaan tidak berpengaruh terhadap minat beli ulang konsumen.

Pada saat konsumen pertama kali bertransaksi, konsumen akan merasa kesulitan karena belum mengetahui bagaimana prosedur bertransaksi pada situs online, dan tidak setiap situs online menerapkan prosedur transaksi yang sama. Konsumen cenderung mengurungkan niatnya untuk berbelanja secara online jika mengalami kesulitan dalam proses bertransaksi. Mudah atau tidaknya prosedur bertransaksi pada situs Tumbasin.id tidak akan menyebabkan perubahan terhadap minat beli ulang. Tidak berpengaruhnya kemudahan penggunaan terhadap minat beli ulang disebabkan karena konsumen merasa tampilan dan pengoprasian pada situs Tumbasin.id masih mudah untuk dimengerti, situs Tumbasin.id juga masih mudah dipelajari, fleksibel dan nyaman untuk bertransaksi. Sehingga konsumen tidak perlu mempertimbangkan kemudahan penggunaan dalam bertransaksi dan kemudahan penggunaan tidak mengurangi minat beli ulang konsumen.

Hasil penelitian ini didukung oleh penelitian yang dilakukan Yuliawan, et al. (2018) yang menunjukkan bahwa kemudahan penggunaan memiliki pengaruh positif tapi tidak signifikan, dikarenakan faktor kemudahan penggunaan bergantung pada bagaimana operasional bertransaksi secara online. Penelitian menurut Ahmad dan Pambudi (2014) juga mendapatkan hasil yang sama bahwa kemudahan penggunaan tidak berpengaruh terhadap minat ulang nasabah yang menggunakan layanan internet banking BRI.

\section{KESIMPULAN DAN SARAN}

\section{Kesimpulan}

Promosi $\left(\mathrm{X}_{2}\right)$ dan kepercayaan $\left(\mathrm{X}_{3}\right)$ berpengaruh signifikan terhadap minat beli ulang (Y), sementara harga $\left(\mathrm{X}_{1}\right)$ dan kemudahan 
penggunaan situs $\left(\mathrm{X}_{4}\right)$ tidak berpengaruh terhadap minat beli ulang (Y).

\section{Saran}

Tumbasin.id yaitu agar selalu memonitor harga yang ditetapkan, sehingga sesuai dengan perubahan harga di pasaran, agar harga tidak terlalu tinggi dan bersaing dengan situs online lainnya.

Permudah pengoperasian situs Tumbasin.id karena tanpa prosedur bertransaksi yang baik dan mudah, konsumen akan merasa kesulitan dalam menggunakannya dan merasa terlalu banyak usaha yang dibutuhkan untuk dapat berbelanja secara online.

\section{DAFTAR PUSTAKA}

Ahmad dan Pambudi, B.S.. 2014. Pengaruh Persepsi Manfaat, Persepsi Kemudahan, Keamanan dan Ketersediaan Fitur Terhadap Minat Ulang Nasabah Bank dalam Menggunakan Internet Banking (Studi pada Program Layanan Internet Banking BRI). Jurnal of Management Studies. 8 (1): 1-11.

Aptaguna, A. dan E. Pitaloka. 2016. Pengaruh Kualitas Layanan dan Harga terhadap Minat Beli Jasa Go-Jek. Widyakala. Journal of
Pembangunan Jaya University. Vol 3: 49-56.

Benson, R. J., T. L. Bugnitz, and W. B. Walton. 2007. From Business Strategy to IT Action. Right Decisions for a Bottom Line. John Wiley and Sons, Inc. New Jersey.

Fandiyanto, R., R.A. Sularso dan B. Irawan. 2017. Pengaruh Kemudahan, Keamanan, Ketanggapan, Harga dan Reputasi Perusahaan terhadap Kepercayaan dan Keputusan Pembelian Produk Kerajinan Danbo Secara Online. Jurnal Ekonomi dan Bisnis Growth. 15 (1): -

Gitosudarmo, I. 2000. Manajemen Pemasaran, Edisi Pertama. Cetakan Keenam, BPFE. Yogyakarta.

Jackson, R.S.W. 2013. Kualitas Produk, Harga, Promosi, dan Kualitas Pelayanan Pengaruhnya Terhadap Keputusan Pembelian Springbed. Jurnal Emba. 1 (4): 607-618.

Kotler, P. 1996. Manajemen Pemasaran : Maketing Management. PT. Prenhallindo. Jakarta.

Kotler, P. 2008. Manajemen Pemasaran (Edisi $12 \mathrm{~J}$ ). Indeks. Jakarta.

Mandey, J.B. 2013. Promosi, Distribusi, Harga Pengaruhnya terhadap Keputusan Pembelian Rokok Surya Promild. Jurnal Emba. 1 (4): 95-104. 
McLeod, R. Jr., dan Schell, G.P.. 2008. Sistem Informasi Manajemen Edisi 10. Salemba Empat. Jakarta.

Moorman, C., R. Deshpande, and G. Zaltman. 1993. Factors Affecting Trust in Market Research Relationships. Journal of Marketing. 57 (1): 81-101.

Murwatiningsih dan E.P. Ariliani. 2013. Apakah Kepercayaan Konsumen Lebih Efektif daripada Risiko dan Harga? Jurnal Dinamika Manajemen. 4 (2): 180-187.

Setyarko, Y. 2016. Analisis Persepsi Harga, Promosi, Kualitas Layanan, dan Kemudahan Penggunaan Terhadap Keputusan Pembelian Produk Secara Online. Jurnal Ekonomika dan Manajemen. 5 (2): 128-147.

Swastha, B. dan Irawan. 2001. Manajemen Pemasaran Modern. Liberty. Yogyakarta.

Tjiptono, F. 2001. Manajemen Pemasaran dan Analisa Perilaku Konsumen. BPFE. Yogyakarta.

Tjiptono, F. 2005. Pemasaran Jasa. Bayumedia Publishing. Yogyakarta.

Yousafzai, S. Y., J.G. Pallister, and G.R. Foxall. 2003. A Proposed Model of E-Trust for Electronic Banking. Technovation. 23: (847-860).

Yuliawan, E., H. Siagian, dan L. Willis. 2018. Analisis Pengaruh Faktor Kepercayaan, Kemudahan dan Kualitas
Layanan Terhadap Keputusan Pembelian pada Online Shop Zalora Indonesia (Studi pada Mahasiswa Program Studi Manajemen STIE Mikroskil Medan). Optimal: Jurnal Ekonomi dan Kewirausahaan. 12 (2): 34-49. 